WOJCIECH KRIEGSEISEN

Instytut Historii PAN, Warszawa

\title{
REGION HISTORYCZNY EUROPY ŚRODKOWO-WSCHODNIEJ W BADANIACH NAD DZIEJAMI WYZNANIOWYMI EPOKI NOWOŻYTNEJ
}

Emanuel Rostworowski, jeden z najwybitniejszych polskich badaczy dziejów nowożytnych, mawiał, że cezury chronologiczne bywają tematem rozważań historyków wtedy, gdy nie mają nic ciekawszego do powiedzenia. Być może do podobnej kategorii „tematów zastępczych” można zaliczyć niektóre teoretyczne wątki dyskusji poświęconych historycznym podziałom i regionom Europy. Wydaje się bowiem, że poświęcone tylko sprawom terminologicznym lub precyzowaniu granic rozważania na temat tzw. europejskich regionów historycznych nie mają same w sobie szczególnej wartości poznawczej, a można je uprawiać dość bezpiecznie, bo są to zagadnienia z rodzaju ostatecznie nierozwiązywalnych. Często nawiązują do tak popularnych u schyłku XX w. publicystycznych dyskusji na temat przynależności krajów „nowej Europy” do Europy „starej”, czyli „prawdziwej”, a więc są w pewnym sensie kontynuacją prowadzonych w Europie Zachodniej, w okresie budowania instytucjonalnych fundamentów wspólnoty europejskiej, poszukiwań korzeni oraz istoty „europejskiej tożsamości”"

Polskie dyskusje tego rodzaju dość często z kolei nawiązywały do starej, ale nadal żywotnej tradycji przeciwstawiania „naszej” europejskiej wolności „ich” azjatyckiemu despotyzmowi ${ }^{2}$.W odleglejszej przeszłości miało to także wyraźny aspekt wyznaniowy, w którym wolność europejskich

${ }^{1}$ Zob. bibliografię opracowaną przez Rolfa-Joachima Sattlera pt. Europa. Geschichte und Aktualität des Begriffes, Braunschweig 1971, Schriftenreihe des Internationalen Schulbuchinstituts, 16 .

${ }^{2}$ E. Kuźma, Mit Orientu i kultury Zachodu w literaturze XIX i XX wieku, Szczecin 1980; B. Geremek, Więź i poczucie wspólnoty w średniowiecznej Europie, w: Dziesięć wieków Europy. Studia z dziejów kontynentu, red. J. Żarnowski, Warszawa 1983, s. 19-81. 
chrześcijan - poddanych władców „z łaski Bożej” lub nawet, jak w Rzeczypospolitej, z tytułu „umowy o władzę" - przeciwstawiano zniewoleniu, któremu podlegali poddani barbarzyńskich w istocie władców prawosławnych czy islamskich. Na tym fundamencie ukształtowała się przecież tak popularna teoria „przedmurza” chrześcijańskiej (później już tylko katolickiej) Europy ${ }^{3}$.Zakwestionowało ją dopiero oświecenie, które dokonało zasadniczej redefinicji pojęć w zakresie kultury i cywilizacji europejskiej, a w Polsce zainicjowało refleksję samokrytyczną oraz narastające poczucie potrzeby modernizacji zwanej też często wprost „europeizacją"4. Jednak ta ostatnia idea zaowocowała podkreślanym przez Andrzeja Wierzbickiego paradoksem - społeczeństwa wschodnioeuropejskie uznające swe zacofanie i potrzebę „doganiania Zachodu” przyznawały tym samym, że $\mathrm{W}$ istocie do niego nie należą ${ }^{5}$ W ten sposób powstał tak ważny dla myśli polskiej w XIX w., choć funkcjonujący do dziś kompleks „cywilizacyjnej młodszości" europejskiego Wschodu wobec Zachodu'.

Wydaje się więc, że obecnie naukowe rozważania na temat europejskiej tożsamości, a w szczególności przynależności do określonych (częściej niedookreślonych) regionów historycznych, znajdować powinny uzasadnienie przede wszystkim w kontekście projektów badawczych, których celem jest rozwiązanie konkretnych problemów z wykorzystaniem choćby tylko badań porównawczych. Dotyczy to także praktyki stosowania tak istotnego dla historiografii polskiej pojęcia „Europa Środkowo-Wschodnia”, które od czasu przedstawienia przez Oskara Haleckiego w 1950 r. propozycji podziału Europy na cztery regiony historyczne - było już wielokrotnie dyskutowane ${ }^{7}$. Do jego popularyzacji w latach osiemdziesiątych XX w., kiedy to

${ }^{3} \mathrm{~J}$. Tazbir, Polskie przedmurze chrześcijańskiej Europy. Mity a rzeczywistość historyczna, Warszawa 1987; A. Wierzbicki, Europa w polskiej myśli historycznej i politycznej XIX i XX wieku, Warszawa 2009, s. 20-21.

${ }^{4}$ L. Wolff, Inventing Eastern Europe. The map of civilization on the mind of the Enlightenment, Stanford 1994, s. 356-374; J. Michalski, Sarmatyzm a europeizacja Polski w XVIII wieku, w: idem, Studia historyczne z XVIII i XIX wieku, t. 2: Ideologia. Nauka. Historiografia, Warszawa 2007, s. 7-36.

${ }^{5}$ A. Wierzbicki, op. cit., s. 27-38.

${ }^{6}$ J. Jedlicki, Jakiej cywilizacji Polacy potrzebują. Studia z dziejów idei i wyobraźni XIX wieku, Warszawa 1988, Polska XIX i XX wieku. Dzieje społeczne, red. J. Żarnowski, s. 19-76.

${ }^{7}$ O. Halecki, The limits and divisions of European history, New York 1950; przekład polski pt. Historia Europy - jej granice i podziały, red. nauk. H. Łaszkiewicz, przedm. J. Kłoczowski, Lublin 1994, Biblioteka Europy Środkowo-Wschodniej, t. 1. Na temat genezy i znaczenia propozycji Haleckiego ostatnio zob. m.in. H.-J. Bömelburg, Zwischen imperialer Geschichte und Ostmitteleuropa als Geschichtsregion. Oskar Halecki und die polnische ,jagiellonische Idee", w: Vergangene Gröse und Ohnmacht in Ostmitteleuropa. Repräsentationen imperialer Erfahrung in der Historiographie seit 1918, red. F. Hadler, M. Mesenhöller, Leipzig 2007, s. 99-133; P. S. Wandycz, Oskar Halecki i jego koncepcja Europy Środkowo-Wschodniej, „Rocznik Instytutu Europy Środkowo-Wschodniej” 5, 2007, s. 45-51; M. Kornat, Historyk 
losy próbujących wyzwolić się spod sowieckiej dominacji społeczeństw tej części Europy przyciągały powszechną uwagę, najbardziej chyba przyczyniła się rozprawa węgierskiego historyka Jenő Szücsa, opublikowana pierwotnie po węgiersku, ale szybko przetłumaczona na angielski i francuski ${ }^{8}$. Szücs proponował uznać za region Europy Środkowo-Wschodniej terytoria leżące na wschód od dawnej granicy państwa karolińskiego, tj. linii Łaby Soławy (Saale) - Litawy i zachodniej granicy Panonii, a na zachód od ziem nad dolnym Dunajem, Karpat Wschodnich i dalej na północ wzdłuż granicy oddzielającej Słowian zachodnich od wschodnich?.

Warto też pamiętać o niemieckim wkładzie w teorię badań nad Europą Środkowo-Wschodnią. Mamy tu przede wszystkim na uwadze, ważne dla utrwalenia i pogłębienia wypracowanej przez Haleckiego koncepcji regionu historycznego, a także eliminacji nacjonalistycznych i imperialistycznych tradycji prezentowania dziejów Europy Wschodniej, prace jednego z najwybitniejszych współczesnych historyków niemieckich, Klausa Zernacka, a także wydaną przez niego z rękopisu książkę Wernera Conze ${ }^{10}$. W ujęciu tego ostatniego nowożytna Europa Środkowo-Wschodnia obejmowała szeroko pojmowane terytoria czeskie, węgierskie i polskie wraz z Wielkim Księstwem Litewskim, Inflantami i Pomorzem. Do koncepcji innych, czynnych na tym polu niemieckich badaczy, przede wszystkim Gottfrieda Schramma i Michaela G. Müllera, odwołamy się jeszcze niżej.

Zasadniczo można uznać, że pojęcie regionu historycznego Europy Środkowo-Wschodniej przyjęło się nie tylko w polskiej, ale także w stosowanej przez naszych sąsiadów terminologii naukowej ${ }^{11}$. Być może najlepszym tego dowodem jest zmiana tytułu wydawanego przez Instytut

Europy Środkowo-Wschodniej. Oskar Halecki (1891-1973) w nauce i życiu Polski, w: Historik $v$ proměnách doby a prostředí - 20. století, red. J. Hanuš, R. Vlček, Brno 2009, s. 305-338.

${ }^{8}$ J. Szücs, Vázlat Európa három történeti régiójáról, Budapest 1981; idem, The three historical regions of Europe, „Acta Historica Academiae Scientiarum Hungaricae” 29, 1983, 2/4, s. 131-184; idem, Les trois Europes, wstęp F. Braudel, Paris 1985.

${ }^{9}$ Idem, Trzy Europy, red. nauk. H. Łaszkiewicz, przedm. J. Kłoczowski, Lublin 1995, Biblioteka Europy Środkowo-Wschodniej, t. 2, s. 29-34.

${ }^{10}$ K. Zernack, Osteuropa. Eine Einführung in seiner Geschichte, München 1977; por. też rozważania tegoż autora nt. pojęcia północno-wschodniej Europy: idem, Główne problemy historii pótnocno-wschodniej Europy, ZH 50, 1985, 4, s. 25-38; W. Conze, Ostmitteleuropa. Von der Spätantike bis zum 18. Jahrhundert, red. i posłowie K. Zernack, München 1992, s. 105-142. Zmarły w 1986 r. W. Conze był postacią kontrowersyjną, ciążyła na nim nazistowska przeszłość, ale jego osiągnięcia po 1945 r. zasługują na uwagę, zob. G. Aly, Theodor Schieder, Werner Conze oder die Vorstufen der physischen Vernichtung, w: Deutsche Historiker im Nationalsozialismus, red. W. Schulze, O.G. Oexle, Frankfurt a. M. 1999, s. 163-182, i T. Etzemüller, Sozialgeschichte als politische Geschichte. Werner Conze und die Neuorientierung der westdeutschen Geschichtswissenschaft nach 1945, München 2001.

${ }^{11}$ J. Kłoczowski, Europa Środkowowschodnia w historiografii krajów regionu, Lublin 1993, Materiały Instytutu Europy Środkowo-Wschodniej, t. 5, passim. 
Herdera w Marburgu czasopisma naukowego, które do 1994 r. publikowane było jako „Zeitschrift für Ostforschung”, a od tego roku ukazuje się jako „Zeitschrift für Ostmitteleuropa-Forschung”, zajmując się głównie zagadnieniami dotyczącymi historii i kultury na obecnych terytoriach Polski, Czech, Słowacji, Białorusi, Ukrainy, Litwy, Łotwy i Estonii ${ }^{12}$. W rok później powołano w Lipsku centrum badawcze (Geisteswissenschaftliches Zentrum Geschichte und Kultur Ostmitteleuropas), wcześniej, w latach 1992-1995, działające w Berlinie jako Forschungsschwerpunkt Geschichte und Kultur Ostmitteleuropas, a obecnie związane ściśle z uniwersytetem w Lipsku, którego zadaniem jest prowadzenie badań nad historią i kulturą Europy Środkowo-Wschodniej definiowanej szeroko, jako obszar pomiędzy Bałtykiem, Morzem Czarnym i Adriatykiem ${ }^{13}$.

Dla współczesnej polskiej historiografii decydujące znaczenie miały oczywiście prace publikujących w kraju i na emigracji polskich badaczy.Już w 1985 r. Bronisław Geremek wydał cenne także w tym zakresie rozważania na temat Polski w geografii kulturowej Europy średniowiecznej ${ }^{14}, w 1992$ r. ukazała się syntetyczna książka Piotra Wandycza ${ }^{15}$, a wreszcie w 1998 r. praca Jerzego Kłoczowskiego o „młodszej Europie” ${ }^{16}$. Największe jednak zasługi dla popularyzacji pojęcia regionu historycznego Europy Środkowo-Wschodniej położyło po 1989 r. Towarzystwo Instytutu Europy Środkowo-Wschodniej. Od 2001 r. działa w Lublinie kierowany przez J. Kłoczowskiego Instytut Europy Środkowo-Wschodniej, wydający pod jego redakcją od 2003 r. „Rocznik Instytutu Europy Środkowo-Wschodniej”" ${ }^{17}$. Wokół Instytutu i jego czasopisma od dawna skupia się międzynarodowe środowisko zainteresowane nie tylko historią, ale i współczesnością tego regionu ${ }^{18}$.

${ }_{12}$ Zob. 〈http://www.herder-institut.de/servicebereiche/verlag/zfo-zeitschrift -fuer-ostmitteleuropa-forschung.html > (dostęp: 7 XI 2013). Trudno orzec, do jakiego stopnia na decyzji o zmianie nazwy pisma zaważyła potrzeba rozstania się z tradycją źle postrzeganego, szczególnie w Europie Wschodniej, „Ostforschung”.

${ }^{13}$ Zob. 〈http://www.uni-leipzig.de/gwzo/〉 (dostęp: 7 XI 2013).

${ }^{14}$ B. Geremek, Polska w geografii kulturowej średniowiecznej Europy, w: Kultura Polski średniowiecznej X-XIII wieku, red. J. Dowiat, Warszawa 1985, s. 8-26.

${ }_{15}$ P.S. Wandycz, The price of freedom. A history of East Central Europe from Middle Ages to the Present, London-New York 1992; przekład polski: Cena wolności. Historia Europy Środkowo-Wschodniej od średniowiecza do współczesności, Kraków 1995. Podobne ujęcie znajdujemy w wydanym niedawno zbiorze prac tegoż autora: idem, 0 czasach dawnych i bliższych. Studia z dziejów Polski i Europy Środkowo-Wschodniej, Poznań 2009.

${ }_{16}$ Tytułowa „młodsza Europa” to region historyczny Europy Środkowo-Wschodniej definiowany nieostro: „Trzonem tej Europy pozostają historyczne obszary związane z Polską, Czechami i Węgrami, trzema monarchiami ukształtowanymi w X-XII stuleciu", J. Kłoczowski, Młodsza Europa. Europa Środkowo-Wschodnia w kręgu cywilizacji chrześcijańskiego średniowiecza, Warszawa 1998, s. 11.

$17\langle$ http://www.iesw.lublin.pl/rocznik/〉 (dostęp: 7 XI 2013).

${ }^{18}$ J. Kłoczowski, Europa Środkowowschodnia w historiografii, s. 33-37. 
Cechą charakterystyczną wymienionych wyżej prac, a także licznych, cennych publikacji historycznych lubelskiego Instytutu, jest syntetyczny i przeglądowy charakter. Nieco inaczej, by nie napisać wprost - gorzej, wygląda stan badań naukowych nad problemami szczegółowymi, wspólnymi i istotnymi dla dziejów społeczeństw Środkowo-Wschodniej Europy. Przewaga syntetycznych opracowań nad szczegółowymi studiami problemowymi wynika zapewne stąd, że w polskiej historiografii pojęcie to - z założenia termin badawczy - nadal występuje często w sensie metaforycznym, by per analogiam przywołać rozważania B. Geremka dotyczące terminologii historii społecznej ${ }^{19}$. „Metaforyczność” w tym wypadku tylko po części polega na podnoszonej przez Geremka zamierzonej nieostrości znaczeniowej pewnych pojęć. Większą wagę ma tu chyba swoisty „rewizjonizm” terminu „Europa Środkowo-Wschodnia”. Ma on przypominać historykom „świata zachodniego" o dziejach tych społeczeństw europejskich, które po II wojnie światowej wbrew swej woli znalazły się w orbicie wpływów sowiec$\mathrm{kich}^{20}$. O ile w wypadku O. Haleckiego i jego bezpośrednich kontynuatorów ta suigeneris polityka historyczna była nie tylko zrozumiała, ale i godna szacunku, o tyle skupianie się obecnie na tym aspekcie problemu nie wydaje się szczególnie inspirujące, a niekiedy zakrawa nawet na odreagowywanie wobec „Zachodu” kompleksu peryferii ${ }^{21}$.

Wydaje się, że najważniejszym kryterium oceny kategorii regionu historycznego powinna być funkcjonalność badawcza. W studiach nad dziejami nowożytnymi regionu definiowanego jako Europa Środkowo-Wschodnia potwierdzone to zostało jak dotychczas przede wszystkim w obszarze problematyki polityczno-ustrojowej oraz w studiach nad kulturą polityczną. Zdecydowanie mniejsze zainteresowanie budzą obecnie - tak żywo dyskutowane w połowie XX w. - zagadnienia historii

${ }^{19}$ Występowanie w aparacie pojęciowym historyków „terminów metaforycznych" Geremek uznawał za wartościowe, ponieważ ich użycie zapobiega powstawaniu „przegrody języka technicznego między historykiem a odbiorcą literatury historycznej”, B. Geremek, Uwagi o pojęciu „mas” w historii społecznej, RHum 34, 1989, 2, s. 199. Sądzę, że należy bardzo starannie wyważać bilans korzyści i strat wynikających z posługiwania się nieostrymi terminami.

${ }^{20} \mathrm{~J}$. Kłoczowski, Oskar Halecki i jego walka o miejsce Polski w Europie, w: Z dziejów polityki i dyplomacji polskiej. Studia poświęcone pamięci Edwarda hr. Raczyńskiego, Prezydenta Rzeczypospolitej na wychodźstwie, red. H. Bułhak, Warszawa 1994, s. 397-406; R. Stobiecki, Twórczość emigracyjna Oskara Haleckiego (1891-1973). Próba charakterystyki, w: Studia z dziejów Polski i Europy w XIX i XX wieku. Księga dedykowana Profesorowi Piotrowi Stanisławowi Wandyczowi, red. J. Faryś, R. Nir, M. Szczerbiński, Gorzów Wielkopolski 2004, s. 581-592. Zob. też J. Cisek, Oskar Halecki. Historyk - Szermierz Wolności, Warszawa 2009, oraz Oskar Halecki i jego wizja Europy, t. 1, red. M. Dąbrowska, Warszawa-Łódź 2012.

${ }^{21} \mathrm{~Np}$. E. Znamierowska-Rakk, Pojęcie i tożsamość Europy Środkowo-Wschodniej w historiografii makroregionu i opinie elit Zachodu, SDRE 45, 2010, s. 5-20. 
gospodarczej tego regionu. Co prawda Krzysztof Brzechczyn kilkanaście lat temu podjął ponownie wątek odrębności gospodarczego rozwoju Europy Środkowej w stosunku do Zachodu w nawiązaniu do teorii „granicy Łaby" i ekonomiki folwarczno-pańszczyźnianej dominującej na wschód od niej, ale jego studium ma charakter teoretyczno-metodologiczny i do naszej wiedzy o regionalnych procesach gospodarczych nie wnosi wiele nowego ${ }^{22}$.

Już wspominany wyżej J. Szűcs podkreślał specyfikę społeczno-ustrojową regionu środkowo-wschodnioeuropejskiego z jego elitami politycznymi przywiązanymi do porządku stanowego. W szczególności dotyczy to społeczeństw czeskiego i węgierskiego, które od początku epoki nowożytnej starały się przeciwstawiać tendencji centralistycznej i następnie absolutystycznej reprezentowanej przez Habsburgów ${ }^{23}$. Z analogiczną do pewnego stopnia tendencją ustrojową mamy do czynienia w Koronie Królestwa Polskiego, gdzie ustrój stanowy przekształcił się w XVI w. w system tzw. demokracji szlacheckiej. Obawa przed wzmocnieniem władzy królewskiej na wzór węgierski po „złym kompromisie” węgierskiej szlachty z Habsburgami w 1526 r., czy nawet przed absolutum dominium jak w Czechach po klęsce stanów w 1620 r. aż po schyłek XVIII w., stanie się jedną z charakterystycznych cech kultury politycznej polsko-litewskiej Rzeczypospolitej szlacheckiej ${ }^{24}$.

Tę koncepcję koncentrująca się na problematyce politycznej rozwijał w latach osiemdziesiątych przywoływany wyżej G. Schramm, który argumentował na rzecz tezy, iż swoisty, odrębny od Wschodu i Zachodu, typ kultury politycznej wypracowany po 1500 r., wspólny dla szlachty polskiej, czeskiej i węgierskiej, stanowi przykład europejskiej kultury regionalnej. Konkluzja tych rozważań odnosiła się do żywo niegdyś dyskutowanej tezy o „naturalnym” czy „typowym” rozwoju europejskich systemów politycznych epoki wczesnonowożytnej od ustroju stanowego ku absolutyzmowi ${ }^{25}$.

${ }^{22}$ K. Brzechczyn, Odrębność historyczna Europy Środkowej. Studium metodologiczne, Poznań 1998.

${ }^{23}$ J. Szücs, Trzy Europy, s. 88 nn.

${ }^{24}$ S. Russocki, Monarchie stanowe środkowo-wschodniej Europy XV-XVII wieku, KH 84, 1977, 1, s. 73-92; E. Opaliński, Kultura polityczna szlachty polskiej w latach 1587-1652. System parlamentarny a społeczeństwo obywatelskie, Warszawa 1995, s. 108-109; A. Grześkowiak-Krwawicz, Regina libertas. Wolność w polskiej myśli politycznej XVIII wieku, Gdańsk 2006, s. 189-214; U. Augustyniak, Historia Polski 1572-1795, Warszawa 2008, s. 193, 533, 586.

${ }^{25}$ Zob. m.in. W. Hubatsch, Das Werden des Absolutismus, Braunschweig 1966; N. Henshall, The myth of absolutism. Change and continuity in early modern European monarchy, London-New York 1992; H. Duchhardt, „Absolutismus”- Abschied von einem Epochenbegriff?, „Historische Zeitschrift” 258, 1994, s. 113-122; Der Absolutismus - ein Mythos? Strukturwandel monarchischer Herrschaft in West- und Mitteleuropa (ca.1550-1700), red. R. G. Asch, H. Duchhardt, Köln-Weimar-Wien 1996. 
Zdaniem Schramma system stanowy niekoniecznie musiał być tylko przejściową formą ustrojową prowadzącą ku wczesnemu absolutyzmowi ${ }^{26}$.

Dobrym przykładem praktycznego, badawczego zastosowania takiego podejścia do problematyki środkowo-wschodnioeuropejskich państw stanowych są studia austriackich, czeskich, niderlandzkich, niemieckich, polskich oraz węgierskich historyków opublikowane w 1996 r. przez Hansa-Jürgena Bömelburga i Norberta Kerskena w tomie zbiorowym wydanym w 1996 r. w Lipsku w serii Forschungen zur Geschichte und Kultur des östlichen Mitteleuropa i zaopatrzone w instruktywne podsumowanie pióra Winfrieda Eberharda ${ }^{27}$. Problematyka ta była także przedmiotem dyskusji historyków niemieckich w 1999 r. we Fryburgu. Przydatność badawczą terminu „Europa Środkowo-Wschodnia" potwierdzono tam m.in. z uwagi na wspólnotę nowożytnego doświadczenia historycznego krajów Korony św. Stefana, Korony św. Wacława (do 1620 r.) oraz Rzeczypospolitej przede wszystkim właśnie w zakresie ustrojowym. Decydowała o niej zasada niepodzielności terytorium, elekcyjny charakter monarchii, dominacja stanu szlacheckiego oraz zdecydowany opór przeciw absolutystycznym zakusom monarchii. G. Schramm podsumował dyskusję mocnym stwierdzeniem, że Europa Środkowo-Wschodnia nie jest konstruktem historyków i badaczy kultury, ale historyczną rzeczywistością uchwytną najwyraźniej w podobieństwach strukturalnych społeczeństw stanowych (po 1500 r.), choć stwierdził też postępujący zanik tych polsko-czesko-węgierskich analogii po $1620 \mathrm{r}^{28}$

Stosunkowo niedawno głos $w$ dyskusji na temat badawczego zastosowania pojęcia „Europa Środkowo-Wschodnia” zabrał inny znawca stosunków polsko-niemieckich, uczeń K. Zernacka, M.G. Müller. Akceptując,

${ }^{26}$ Pierwsza wersja przedstawiona została przez autora na spotkaniu polskich i niemieckich historyków w Moguncji w 1984 r., a następnie opublikowana w „Przeglądzie Historycznym” - G. Schramm, Polen, Böhmen, Ungarn. Übernationale Gemeinsamkeiten in der politischen Kultur des späten Mittelalters und der frühen Neuzeit, PH 76, 1985, 3, s. 417-437; zob. też: idem, Polen - Böhmen - Ungarn. Übernationale Gemeinsamkeiten in der politischen Kultur im 16.-18. Jahrhundert, w: Crown, church and estates. Central European politics in the sixteenth and seventeenth centuries, red. R.J.W. Evans, T.V. Thomas, New York-London 1991, s. 176-195, oraz idem, Polen - Böhmen - Ungarn. Übernationale Gemeinsamkeiten in der politischen Kultur des späten Mittelalters und der frühen Neuzeit, w: Ständefreiheit und Staatsgestaltung in Ostmitteleuropa. Übernationale Gemeinsamkeiten in der politischen Kultur vom 16.-18. Jahrhundert, red. H.-J. Bömelburg, N. Kersken, Leipzig 1996, s. 13-38. Korzystamy z wydania polskiego: G. Schramm, Polska - Czechy - Wegry. Wspólne cechy kultury politycznej trzech krajów w późnym średniowieczu i wczesnym okresie nowożytnym, w: idem, Polska w dziejach Europy Środkowej. Studia, Poznań 2010, s. 19-45.

${ }^{27}$ W. Eberhard, Ständische Strukturen in Ostmitteleuropa. Problemstellungen und Thesen. (Eine vorläufige Diskussionsbilanz), w: Ständefreiheit und Staatsgestaltung in Ostmitteleuropa, s. 311-318.

${ }^{28}$ G. Schramm, Wokót pojęcia „Europy Środkowo-Wschodniej”. Dyskusja panelowa, w: idem, Polska w dziejach, s. 11-17. 
za Szűcsem i Zernackiem, jako warunek konieczny przekonującej definicji regionu wspólne w długim trwaniu doświadczenie historyczne jego mieszkańców, omówił kilka tego przykładów, z których dla historyka nowożytnego szczególnie interesująca jest problematyka gospodarki folwarczno-pańszczyźnianej, zjawisko trwałości ustroju stanowego, wreszcie specyficzna kultura Żydów wschodnioeuropejskich. Podobnie jak wcześniej Schramm, Müller zwraca uwagę, że jednak żadne z tych zjawisk nie spełnia warunku pełnej ciągłości w czasie (epoka nowożytna) i wyłączności w przestrzeni (Europa Środkowo-Wschodnia). Problem gospodarki pańszczyźnianej dotyczył nie tylko Czech, Węgier i Rzeczypospolitej, ale także wschodnich Niemiec i Rosji. Ustrój stanowy przetrwał po schyłek XVIII w. tylko w Rzeczypospolitej szlacheckiej, a jego likwidacja w Czechach już w XVII w. może być nawet rozważana jako podstawa dla późniejszej modernizacji ziem czeskich. Z kolei formacja kulturowa wschodnioeuropejskiego żydostwa charakterystyczna była tylko dla ziem dawnej Rzeczypospolitej ${ }^{29}$.

Negując niezbędność chronologicznej i przestrzennej ciągłości zjawisk dziejowych badanych w wymiarze regionalnym oraz odwołując się do rozważań Krzysztofa Pomiana oraz Miroslava Hrocha, który apelował niedawno, by o Europie Środkowo-Wschodniej jako o regionie mówić tylko w konkretnym kontekście historycznym, Müller przywołuje dyskusje antropologów nad przestrzennym wymiarem badań społecznych i postuluje potrzebę każdorazowego, ,roboczego” definiowania rozpatrywanej przez badacza przestrzeni jako regionu historycznego w kontekście konkretnego projektu. W konsekwencji oznaczałoby to jednak odejście w narracjach historycznych nie tylko od standardowych, ,,ponadczasowych jednostek geograficznych", takich jak kontynenty, państwa, regiony narodowe oraz sub- i transnarodowe na rzecz „wielorakich geografii”, ale zapewne także rezygnację z traktowania narodu wraz z jego przestrzenią jako „naturalnego przedmiotu historiografii" 30 .

Interesujące, że M.G. Müller, historyk tak doświadczony w badaniach nad nowożytnymi stosunkami wyznaniowymi w Europie Środkowo-Wschodniej, nie zwrócił uwagi na ten właśnie aspekt dziejów regionalnych ${ }^{31}$. A przecież wydaje się, że obok gospodarki folwarczno-pańszczyź-

${ }^{29}$ M.G. Müller, Where and when was (East) Central Europe?, w: Domains and divisions of European history, red. J.P. Árnason, N.J. Doyle, Liverpool 2010, s. 112-125; korzystamy z wydania polskiego: idem, Gdzie i kiedy była Europa Środkowo (Wschodnia)?, w: idem, Zrozumieć polską historię, Poznań 2012, s. 90-105.

${ }^{30}$ M. G. Müller, Gdzie i kiedy była Europa Środkowo (Wschodnia)?, s. 103-105; por. K. Pomian, L'Europe Centrale. Essai de définition, „Revue germanique internationale” 1, 1994, s. 9-23; M. Hroch, Central Europe. The rise and fall of an historical region, w: Central Europe. Core or periphery?, red. Ch. Lord, Copenhagen 2000, s. 21-34.

${ }^{31}$ Oprócz licznych rozpraw i artykułów poświęconych tej problematyce jest on 
nianej oraz ustroju stanowego to właśnie wysoki poziom religijnego i wyznaniowego zróżnicowania jest jedną z najbardziej charakterystycznych i trwałych cech społeczeństw środkowo-wschodnioeuropejskich. Stara tradycja zróżnicowania religijnego oraz wyznaniowego i związany z ustrojem stanowym wysoki poziom swobód wyznaniowych podnoszony jest najczęściej jako cecha szczególna polsko-litewskiej, wieloetnicznej i wielokulturowej Rzeczypospolitej szlacheckiej ${ }^{32}$.

Już jednak J. Kłoczowski słusznie rozciągnął tę charakterystykę na cały region: „Wiek XVI można uznać za okres takiego współistnienia na całym terenie Europy Środkowo-Wschodniej, kiedy w zestawieniu z absolutyzmami konfesyjnymi zachodnimi i wschodnimi różnych denominacji świadomie sformułowana zasada wolności religijnej i poszanowania dla własnych wyborów miała tak istotne znaczenie w życiu społeczności czeskich, węgierskich, czy licznych ludów skupionych w Rzeczypospolitej polsko-litewsko-ruskiej z Żydami włącznie. [- - ] Trzeba jednak przypomnieć, że ta szesnastowieczna sytuacja była bardzo solidnie przygotowana dzięki rozwiązaniom, które z największym trudem, z oporami wychodzącymi od różnych stron, torowały sobie drogę wcześniej"33. Lubelski historyk ma tu na uwadze nie tylko prawosławie w Królestwie Polskim i Wielkim Księstwie Litewskim oraz w Siedmiogrodzie, ale także czeski husytyzm ${ }^{34}$. Na wielowyznaniowość jako cechę charakterystyczną regionu wskazywał też W. Conze, i choć koncentrował się bardziej na konsekwencjach reformacji, to jednak podkreślał wcześniejszą obecność tu prawosławia i husytyzmu ${ }^{35}$.

Przyjrzyjmy się więc bliżej temu problemowi celem ustalenia, czy rzeczywiście religijna i wyznaniowa różnorodność może być uznana za cechę charakterystyczną Europy Środkowo-Wschodniej. Zacznijmy od Królestwa Polskiego, w epoce nowożytnej północno-zachodniej części środkowo-wchodnioeuropejskiego regionu historycznego. Interesujące, że jeszcze w późnym średniowieczu miało ono względnie jednolitą charakterystykę religijną. Poza stosunkowo nielicznymi grupami żydowskiego mieszczaństwa skupionego w kilku centrach, z których najważniejszym był stołeczny Kraków ${ }^{36}$, dominowało tu chrześcijaństwo

także autorem fundamentalnej pracy dotyczącej stosunków wyznaniowych w miastach Prus Królewskich - M.G. Müller, Zweite Reformation und städtische Autonomie im Königlichen Preußen. Danzig, Elbing und Thorn in der Epoche der Konfessionalisierung (15571660), Berlin 1997.

${ }^{32}$ W. Conze, op. cit., s. 127.

${ }^{33}$ J. Kłoczowski, Młodsza Europa, s. 311.

34 Ibidem, s. 315-324.

35 W. Conze, op. cit., s. 167-218.

${ }^{36}$ Ostatnio na ten temat H. Zaremska, Żydzi w średniowiecznej Polsce. Gmina krakowska, Warszawa 2011; zob. też Z. Noga, Zróżnicowanie etniczne i wyznaniowe mieszczaństwa 
w wyznaniu rzymskokatolickim. Zmiany w tym zakresie rozpoczęły się dopiero w połowie XIV w., kiedy to Królestwo Polskie rozpoczęło ekspansję na południowy wschód. Proces anektowania Rusi Halickiej rozpoczęty ok. 1340 r. doprowadził do przyłączenia rozległych terenów, które w Rzeczypospolitej szlacheckiej tworzyć miały województwo ruskie ze stolicą we Lwowie. Pod władzą Kazimierza Wielkiego znalazła się też znaczna część Wołynia i Podola. Wszędzie tam zamieszkiwała ruska ludność wyznania prawosławnego i nawet intensywny pod polskim panowaniem napływ imigrantów innych wyznań oraz religii nie mógł szybko doprowadzić do radykalnych zmian w krajobrazie wyznaniowym. W efekcie władze Królestwa Polskiego liczyć się musiały z wyznawcami prawosławia i ich religijno-kulturową specyfiką, a przede wszystkim z dobrze zakorzenionymi na Rusi strukturami kościelnymi wschodniego chrześcijaństwa ${ }^{37}$.

Utrzymywanie jeszcze w pierwszej połowie XVI w. na Rusi Czerwonej ograniczeń dla prawosławnego kultu religijnego, zwłaszcza budownictwa cerkiewnego, dyskryminacja prawosławnych w dostępie do godności i urzędów (państwowych i miejskich), a nawet tendencja do traktowania ich jako niechrześcijan jeszcze w 200 lat po włączeniu do Królestwa Polskiego dowodzą ograniczonej efektywności procesów integracyjnych. Nie wiemy, czy wyznaniową oraz etniczną mozaikę na Rusi u progu epoki nowożytnej tworzył więc szereg oddzielonych od siebie na mocy „segregacyjnego” prawa grup, czy może była to jednak wspólnota in statu nascendi, wolno integrująca się ku społeczeństwu wieloetnicznemu i wielowyznaniowemu. A może, ponieważ teoretyczna konstrukcja „społeczeństwa wielokulturowego” nadal budzić może wątpliwości, mamy tu do czynienia ze słabo rozpoznanymi procesami charakterystycznymi dla rejonów, które określa się jako „obszar komunikacji transkulturowej" (transcultural communication zone)? Literatura poświęcona tej problematyce narasta dość szybko w ostatnich latach ${ }^{38}$.

krakowskiego w XVI wieku, w: Między Zachodem a Wschodem. Etniczne, kulturowe i religijne pogranicza Rzeczypospolitej w XVI-XVIII wieku, red. K. Mikulski, A. Zielińska-Nowicka, Toruń 2005, s. 121-128.

${ }^{37}$ J. Drabina, Koegzystencja religii i wyznań w Polsce w latach 1333-1370, „Zeszyty Naukowe UJ”, Studia Religiologica, z. 25, 1992, s. 37-50; A. Janeczek, Ethnicity, religious disparity and the formation of the multicultural society of Red Ruthenia in the late Middle Ages, $\mathrm{w}$ : On the frontier of Latin Europe. Integration and segregation in Red Ruthenia, 1350-1600, red. T. Wünsch, A. Janeczek, Warsaw 2004, s. 15-46.

${ }^{38}$ Literatura nt. specyfiki pogranicza polsko-ruskiego pogranicza, zob. B. Szady, Geografia struktur religijnych $i$ wyznaniowych w Koronie w II połowie XVIII wieku, Lublin 2010, s. 48-108; W. Romanowicz, Pogranicze jako przedmiot badań społecznych, ,,Rozprawy Naukowe Państwowej Szkoły Wyższej im. Papieża Jana Pawła II w Białej Podlaskiej” 1, 
Od dawna też wiadomo, że w wielu sytuacjach badawczych odejście od granicy liniowej na rzecz strefy jest konieczne ${ }^{39}$. W zakresie geografii historycznej proponował to zresztą Tadeusz Manteuffel już w $1929 \mathrm{r}^{40}$ Rezygnacja ze stosowania pojęcia granicy liniowej na rzecz stref przejściowych potwierdzałaby zresztą immanentną „,niedookreśloność” regionów historycznych, a więc zgodna byłaby z referowanym wyżej postulatem M.G. Müllera badania ich nie tyle jako regionów geograficznych, ile konstruowanych ad hoc dla potrzeb badawczych ,przestrzeni historycznych" 41 .

Drugim ważnym czynnikiem decydującym o wielowyznaniowym charakterze nowożytnej Rzeczypospolitej była oczywiście unia polsko-litewska. Wielkie Księstwo Litewskie, którego zachodnie, litewskie i białoruskie obszary tworzą północno-wschodnią część regionu, miało już w średniowieczu zdecydowanie odmienną od Królestwa Polskiego charakterystykę wyznaniową. Litwa wcześniej niż Polska, bo od schyłku XIII w., zaczęła podporządkowywać sobie ziemie ruskie, a po aneksji Wołynia, ziem kijowskiej, smoleńskiej i podolskiej najpierw pogańscy, a potem katoliccy Litwini stali się rządzącą mniejszością wyznaniową w państwie zamieszkiwanym przeważnie przez prawosławnych Rusinów ${ }^{42}$, którzy jeszcze w połowie XVI w. stanowili ok. 75\% ogółu mieszkańców. Wziąwszy pod uwagę stałe zagrożenie ze strony Moskwy, był to poważny problem dla Wielkiego Księstwa Litewskiego, a więc już w pierwszej połowie XV w. rozpoczął się tam proces zrównywania praw politycznych katolików i prawosławnych. W połowie XVI w.w możnowładczej elicie politycznej państwa litewskiego wyznawcy prawosławia stanowili ok. $40 \%{ }^{43}$. Ostatecznie w latach sześćdziesiątych tego

2007, s. 87-97; „Granice” $i$ „pogranicza” w badaniach historycznych $i$ antropologicznych, red. P. Figurski, M. Sas, Warszawa 2012; Pogranicza kulturowe w Europie średniowiecznej. Stowianie i ich sąsiedzi, red. K. Grążawski, M. Dulinicz, Brodnica-Warszawa-Olsztyn 2012.

${ }^{39}$ Zob. np. G. Myśliwski, Powstanie i rozwój granicy liniowej na Mazowszu (XII-pot. XVI w.), KH 101, 1994, 3, s. 3-24.

${ }^{40}$ T. Manteuffel, Metoda oznaczania granic w geografii historycznej, w: Księga pamiątkowa ku uczczeniu dwudziestopięcioletniej działalności naukowej prof. Marcelego Handelsmana, Warszawa 1929, s. 221-228.

${ }^{41}$ M.G. Müller, C. Torp, Conceptualising transnational spaces of history, „European Review of History - Revue européenne d'histoire" 16, 2009, 5, s. 609-617.

${ }^{42}$ W. Kamieniecki, Ograniczenia wyznaniowe w prawodawstwie Wielkiego Księstwa Litewskiego, PH 13, 1911, 3, s. 268-282; T. Śliwa, Kościót prawosławny w państwie litewskim w XII-XIV wieku, w: Chrzest Litwy. Geneza, przebieg, konsekwencje, red. M. T. Zahajkiewicz, Lublin 1990, s. 15-32; por. K. Kiaupa, J. Kiaupienè, A. Kuncevičius, The history of Lithuania before 1795, Vilnius 2000, s. 72-97.

${ }^{43}$ M. Liedke, Świadomość narodowa i udział szlachty oraz możnych ruskich Wielkiego Księstwa Litewskiego w kształtowaniu narodu szlacheckiego Rzeczypospolitej w drugiej połowie XVI wieku, w: Europa Orientalis. Polska i jej wschodni sasiedzi od średniowiecza po wspótczesność. Studia i materiały ofiarowane Profesorowi Stanisławowi Alexandrowiczowi w 65. rocznice 
stulecia Zygmunt August zniósł przepisy ograniczające prawa polityczne prawosławnych, co potwierdziły postanowienia unii lubelskiej z $1569 \mathrm{r}^{44}$

A więc w pierwszej połowie XVI w., kiedy to ferment reformacyjny dotarł do Królestwa Polskiego, a następnie Wielkiego Księstwa Litewskiego i doprowadził do kolejnych podziałów wyznaniowych, tak elity polityczne tych krajów, jak i znaczna część mieszkańców od dawna już oswojone były z konfesyjnym zróżnicowaniem oraz praktycznymi tego konsekwencjami w kulturze, polityce, w życiu religijnym oraz codziennym. Musiało to mieć istotne znaczenie dla dalszego rozwoju stosunków międzywyznaniowych na tych terenach, ale nie należy tego traktować jako fenomenu charakterystycznego tylko dla państwa polsko-litewskiego. Analogiczną, choć odmienną co do genezy tradycję wyznaniowego zróżnicowania w epoce nowożytnej obserwujemy bowiem na ziemiach Korony św. Wacława, czyli w Czechach i związanych z nimi terytoriach: Morawach, margrabstwach Dolnych i Górnych Łużyc oraz księstwach śląskich, które w tym kształcie aż do połowy XVIII w. tworzyły pod władzą Habsburgów rozległy kompleks terytorialny w południowo-zachodniej części regionu ${ }^{45}$.

Jedną z najbardziej charakterystycznych cech społeczeństw ziem czeskich od późnego średniowiecza było bowiem właśnie ich wyznaniowe zróżnicowanie. Kładące kres wojnom husyckim porozumienia praskie i bazylejskie zalegalizowały istnienie odrębnej od Kościoła katolickiego organizacji kościelnej, tzw. Kościoła kalikstynów albo utrakwistycznego. Obowiązywała w nim czeska liturgia, komunia sub utraque specie, nie istniała hierarchia biskupia, a duchowieństwo nie mogło posiadać nieruchomości. Warto też zauważyć, że w wyniku rewolucji husyckiej duchowni stracili w Czechach odrębny status - stany czeskie podejmowały decyzję na zjazdach sejmowych bez ich reprezentacji ${ }^{46}$. Początkowo zresztą, po 1435 r., rozdział pomiędzy katolikami a utrakwistami nie był jasny, a duchowy zwierzchnik utrakwistów Jan Rokyčana wybrany został arcybiskupem praskim ${ }^{47}$.Jednak

urodzin, red. Z. Karpus, T. Kempa, D. Michaluk, Toruń 1996, s. 135-144; H. Grala, Kołpak Witoldowy czy czapka Monomacha? Dylematy wyznawców prawosławia w monarchii ostatnich Jagiellonów, w: Katolicyzm w Rosji i prawosławie w Polsce (XI-XX w.), red. J. Bardach, T. Chynczewska-Hennel, Warszawa 1997, s. 51-67.

${ }^{44}$ W. Czermak, Sprawa równouprawnienia schizmatyków i katolików na Litwie (14321563 r.), RWHF PAU, seria 2, t. 19, 1903, s. 348-405; K. Chodynicki, Geneza równouprawnienia schizmatyków w Wielkim Księstwie Litewskim. Stosunek Zygmunta Augusta do wyznania grecko-wschodniego, PH 22, 1919-1920, s. 54-135.

${ }^{45}$ F. Machilek, Böhmen, w: Die Territorien des Reichs im Zeitalter der Reformation und Konfessionalisierung. Land und Konfession 1500-1650, red. A. Schindling, W. Ziegler, Münster 1989 , s. 134-152.

${ }^{46}$ S. Russocki, op. cit., s. 77.

${ }^{47}$ W. Iwańczak, Katolicy i husyci w czasach Jerzego z Podiebradu, w: Stosunki międzywy- 
jego następcy tytułowani byli już tylko administratorami Kościoła utrakwistycznego, a stosunki z katolikami uregulowano ostatecznie na mocy porozumienia w Kutnej Horze w 1485 r. $^{48}$

Recepcja idei reformacji ewangelickiej w XVI w. rozwijała się więc w społeczeństwie wyznaniowo już wcześniej podzielonym; najpierw na katolików i utrakwistów, a następnie także na luteranów oraz zwolenników znacznie bardziej radykalnego nurtu teologicznego - braci czeskich (Unitas fratrum, Jednota bratř́ českých) ${ }^{49}$. Z drugiej strony już w latach dwudziestych i trzydziestych XVI w. znaczna część utrakwistów (tzw. neoutrakwiści) szukała porozumienia z luteranami ${ }^{50}$. Jednak najpoważniejszym problemem dla rządzącego od 1526 r. Ferdynanda I Habsburga i jego następców okazali się rosnący w siłę bracia czescy, którzy mieli istotny wpływ na politykę stanów czeskich po wybuchu wojny szmalkaldzkiej w 1546 r. ${ }^{51}$ Mimo represji w następnych latach wyznanie czeskobraterskie zdobyło sobie licznych zwolenników w szeregach czeskiej i morawskiej szlachty oraz magnaterii ${ }^{52}$. W rezultacie stało się politycznie najważniejszym nurtem chrześcijaństwa w Czechach, a recepcja przez braci czeskich kalwinizmu w drugiej połowie XVI w. pozwoliła im na początku XVII w. odegrać ważną rolę w polityce czeskiej, a nawet europejskiej ${ }^{53}$.

znaniowe w Europie Środkowej i Wschodniej w XIV-XVII wieku, red. M. Dygo, S. Gawlas, H. Grala, Warszawa 2002, s. 25-37.

${ }^{48}$ W. Eberhard, Entstehungsbedingungen für öffentliche Toleranz am Beispiel des Kuttenberger Religionsfrieden von 1485, „Communio viatorum” 29, 1986, s. 129-154; idem, Zu den politischen und ideologischen Bedingungen öffentlicher Toleranz. Der Kuttenberger Religionsfrieden, „Studia Germano-Polonica” 1, 1992, s. 101-118.

${ }^{49}$ F. Hrubý, Luterství a kalvinismus na Moravě před Bílou horou, „Český časopis historický" 41, 1935, s. 1-40, 237-268; J. Válka, Tolerance, či koexistence? (K povaze soužití různých náboženských vyznání v českých zemích v 15. až 17. století), „Studia Comeniana et historica" 18, 1988, 35, s. 63-75; W. Iwańczak, Kościół w Czechach w XVI w. - dezintegracja i łączność, „Przegląd Humanistyczny” 50, 2006, 3, s. 21-30.

${ }^{50} \mathrm{~F}$. Hrubý, Luterství a novoutrakvismus v českých zemích v 16. a 17. století, „Český časopis historický" 45, 1939, s. 31-44; Z.V. David, Finding the middle way. The Utraquist's liberal challenge to Rome and Luther, Baltimore-London 2003, s. 139-142.

${ }^{51}$ A. Kohler, Ferdinand I and the estates. Between confrontation and cooperation, 15211564, w: Crown, church and estates, s. 48-57; J. Bahlcke, Regionalismus und Staatsintegration im Widerstreit. Die Länder der Böhmischen Krone im ersten Jahrhundert der Habsburgermonarchie (1526-1619), München 1994, s. 127-148.

${ }^{52}$ V. Bůžek, Nižší šlechta v politickém systému a kultuře předbělohorských Čech, Praha 1996, s. 129-161; Z. Vybíral, Politické komunikace aristokratické společnosti českých zemí na počátku novověku, České Budějovice 2005, s. 122-176.

${ }^{53}$ R.J.W. Evans, The making of the Habsburg monarchy, 1550-1700. An interpretation, Oxford 1984, s. 206-207; J. Pánek, Stavovská opozice a její zápas s Habsburky 1547-1577. K politické krizi feudálni tř́dy v předbělohorském českém státě, Praha 1982. 
Wreszcie trzecie rozległe terytorium tworzące w epoce nowożytnej region Europy Środkowo-Wschodniej - Korona św. Stefana i wchodzące w jej skład kraje: Królestwo Węgierskie z Górnymi Węgrami (Słowacja), Chorwacją, Siedmiogrodem, Baczką, Banatem i Burgenlandem zasiedlone było w późnym średniowieczu przez bardzo zróżnicowane pod względem etnicznym, językowym oraz wyznaniowym społeczności. Wschodnie i południowo-wschodnie obszary (Siedmiogród, Banat) zamieszkiwali szczególnie licznie chrześcijanie wyznania prawosławnego (Rusini, Wołosi, Bułgarzy, Serbowie) ${ }^{54}$.

W wyniku osmańskiej ekspansji naznaczonej zdobyciem Belgradu w 1521 r. i spektakularnym zwycięstwem sułtana Sulejmana I nad królem Czech i Węgier Ludwikiem II Jagiellończykiem pod Mohaczem w 1526 r. Korona św. Stefana uległa w 1541 r. podziałowi na dwie strefy wpływów: turecką (Węgry, Siedmiogród, Baczka, Banat) i habsburską (pn.-zach. Węgry i Burgenland, Górne Węgry, Chorwacja). Sytuacja wyznaniowa skomplikowała się dodatkowo przez procesy migracyjne oraz rosnący wpływ różnych wyznań ewangelickich ${ }^{55}$. Największe znaczenie uzyskało w drugiej połowie XVI w. wyznanie ewangelicko-reformowane, a struktury wyznaniowe kalwinizmu dominowały okresowo na terenie Węgier właściwych oraz w Siedmiogrodzie ${ }^{56}$. Z kolei na terenie Górnych Węgier, szczególnie wśród tamtejszych Słowaków, ale także wśród niemieckojęzycznych tzw. Sasów w Siedmiogrodzie, utrwaliło wpływy wyznanie ewangelicko-augsburskie ${ }^{57}$. Wreszcie do dużego znaczenia na tych obszarach doszedł antytrynitaryzm (unitarianizm), którego główne ośrodki ustabilizowały się przede wszystkim wśród ludności węgierskiej w Siedmiogrodzie ${ }^{58}$. Biorąc pod uwagę przedstawicieli

${ }^{54}$ M.Fata, Ungarn, das Reich der Stephanskrone, im Zeitalter der Reformation und Konfessionalisierung, Multiethnizität, Land und Konfession 1500 bis 1700, red. F. Brendle, A. Schindling, Münster 2000, s. 21-30.

${ }^{55}$ G. Adriányi, Die Ausbreitung der Reformation in Ungarn, „Ungarn-Jahrbuch” 5, 1973, s. 66-75; D.P. Daniel, The influence of the Augsburg Confession in South-East Central Europe, ,The Sixteenth Century Journal” 11, 1980, s. 99-114; F. Szakály, Türkenherrschaft und Reformation in Ungarn um die Mitte des 16. Jahrhunderts, w: Etudes Historiques Hongroises, 2, red. F. Glatz, E. Pamlény, Budapest 1985, s. 437-459; K. Péter, Hungary, w: The Reformation in national context, red. B. Scribner, R. Porter, M. Teich, Cambridge 1994, s. $155-167$.

${ }^{56}$ L. Révész, Die helvetische Reformation in Ungarn, „Ungarn-Jahrbuch” 4, 1972, s. 72-100; D.P. Daniel, Calvinism in Hungary. The ideological and ecclesiastical transition to the Reformed faith, w: Calvinism in Europe 1540-1620, red. A. Pettegree, Oxford 1993, s. 205-230.

${ }^{57}$ Die Reformation und ihre Wirkungsgeschichte in der Slowakei. Kirchen- und konfessionsgeschichtliche Beiträge, red. K. Schwarz, P. Švorz, Wien 1996.

${ }^{58}$ Histoire de la Transylvanie, red. B. Köpeczi, Budapest 1989, s. 280-285; K. Reinerth, Die Gründung der evangelischen Kirchen in Siebenbürgen, Köln-Wien 1979, Studia Transyl- 
innych religii, przede wszystkim muzułmanów i żydów, uznać trzeba, że ziemie Korony św. Stefana, tak w części znajdującej się pod wpływem tureckim, jak habsburskim, stanowiły w epoce nowożytnej przykład prawdziwej mozaiki religijnej i wyznaniowej.

Cechą szczególnie charakterystyczną stosunków wyznaniowych w znajdującym się formalnie w tureckiej strefie wpływów księstwie siedmiogrodzkim był przy tym wysoki poziom tolerancji, który w drugiej połowie XVI i pierwszej połowie XVII w. oznaczał polityczne równouprawnienie przedstawicieli czterech głównych wyznań chrześcijańskich: ewangelicko-reformowanego, ewangelicko-augsburskiego, katolickiego oraz unitariańskiego. Mamy tu wyraźną analogię do stosunków międzywyznaniowych na ziemiach czeskich, a szczególnie na Morawach oraz w Rzeczypospolitej szlacheckiej. W znacznie gorszej sytuacji znalazło się w Siedmiogrodzie prawosławie - wyznanie głównie plebejskich poddanych nieposiadających reprezentacji stanowej i pozbawione w związku z tym praw politycznych ${ }^{59}$.

Ważną cechą charakterystyczną stosunków wyznaniowych w Europie Środkowo-Wschodniej było polityczne znaczenie „drugiej reformacji”, rozumianej tu jako rosnące w drugiej połowie XVI w. wpływy wyznania ewangelicko-reformowanego wypierającego luteranizm z pozycji najważniejszego z wyznań ewangelickich. Kalwinizm stawał się w tym okresie wyznaniem elitarnych grup magnacko-szlacheckich, które odgrywały ważną, a niekiedy decydującą rolę na ziemiach czeskich i węgierskich oraz w polsko-litewskiej Rzeczypospolitej. Środowiska czeskich, węgierskich, polskich i litewskich ewangelików reformowanych utrzymywały bliskie stosunki ze współwyznawcami w Europie Zachodniej; należały do międzynarodowej wspólnoty kalwinistów tworzących wtedy w Europie swego rodzaju „wspólną przestrzeń” wyznaniową sięgającą od Siedmiogrodu i Wielkiego Księstwa Litewskiego po Niderlandy i Szkocję ${ }^{60}$. Korespondencja, podróże i studia w tamtejszych ośrodkach

vanica, 5; M. Balázs, Early Transylvanian Antitrinitarism (1566-1571). From Servet to Paleologus, Baden-Baden 1996.

${ }^{59}$ L. Binder, Grundlagen und Formen der Toleranz in Siebenbürgen bis zur Mitte des 17. Jahrhunderts, Köln-Wien 1976, Siebenbürgisches Archiv, 11; G. Murdock, Calvinism on the frontier 1600-1660. International Calvinism and the Reformed Church in Hungary and Transylvania, Oxford 2000, s. 110-142.

${ }^{60}$ F. A. Yates, The Rosicrucian Enlightenment, London-Boston 1972, korzystamy z przekł czeskiego Rozenkrucíanské osvícenství, Praha 2000; R.J. W. Evans, Calvinism in East Central Europe. Hungary and her neighbours', w: International Calvinism 1541-1715, red. M. Prestwick, Oxford 1985, s. 167-196; G. Murdock, op. cit., s. 46-76; J. Csohány, Die politische Beziehungen von Gábor Bethlen zum reformierten Europa, ,Jahrbuch für die Geschichte des Protestantismus in Österreich"110/111, 1994/1995, s. 87-98. 
akademickich nie tylko przynosiły owoce naukowe, artystyczne i literackie, ale musiały mieć także wpływ na kształt i poziom kultury politycznej elit regionu Europy Środkowo-Wschodniej ${ }^{61}$.

Przyjmujemy, że intensywna recepcja kalwinizmu w drugiej połowie XVI w. łączyła się z przyswojeniem uprawianej w tym nurcie teologii politycznej ${ }^{62}$. Mimo że popularna niegdyś teza o kalwinistycznych korzeniach demokracji parlamentarnej nie została zweryfikowana przez późniejsze badania, to nie ma wątpliwości w sprawie wagi, jaką sam Kalwin, a także jego kontynuatorzy przywiązywali do instytucji reprezentacji stanowej ${ }^{63}$. Musiało to być pociągające dla elit politycznych wszędzie tam, gdzie były one wierne ideologii wolności stanowych, a więc także w Europie Środkowo-Wschodniej. U schyłku XVI w. rosnące poczucie zagrożenia wolności stanowych w Czechach i na Węgrzech oraz w Rzeczypospolitej wzmacniane też było przez wolę obrony swobód wyznaniowych przez niekatolików. Zagrożenia płynęły z jednego źródła - ze strony katolickich władz centralnych dążących do osłabienia znaczenia reprezentacji stanowej i rekatolicyzacji ${ }^{64}$. W tym stanie rzeczy obrońcy swobód politycznych i wyznaniowych odwołać się mogli do tej interpretacji prawa oporu, która wypracowana została przez zachodnioeuropejskich kalwinistów w oparciu o doktrynę polityczną Kalwina i tzw. monarchomachów ewangelickich ${ }^{65}$. Obecny stan badań nad antyhabsburską opozycją stano-

${ }^{61} \mathrm{~S}$. Tworek, Działalność oświatowo-kulturalna kalwinizmu małopolskiego (połowa XVI połowa XVIII w.), Lublin 1970; A. Molnár, Reformovaný svět a bratrská šlechta, „Křestanská revue" 38, 1971, s. 140-142; M.E. H. N. Mout, Die politische Theorie in der Bildung der Eliten. Die Lipsius-Rezeption in Böhmen und Ungarn, w: Ständefreiheit und Staatsgestaltung in Ostmitteleuropa, s. 243-264; B. Trencsényi, Patriotism and elect nationhood in early modern Hungarian political discourse, w: Whose love of which country? Composite states, national histories and patriotic discourses in early modern East Central Europe, red. B. Trencsényi, M. Zászkaliczky, Leiden-Boston 2010, s. 499-544.

${ }^{62}$ W. R. Stevenson Jr., Calvin and political issues, w: The Cambridge companion to John Calvin, red. D. K. McKim, Cambridge 2004, s. 173-187; A. Pettegree, The spread of Calvin's thought, w: The Cambridge companion to John Calvin, s. 207-224.

${ }^{63}$ W. Kriegseisen, Stosunki wyznaniowe w relacjach państwo-kościót między reformacja a oświeceniem (Rzesza Niemiecka - Niderlandy Północne - Rzeczpospolita polsko-litewska), Warszawa 2010, s. 184-190; W.J. Stankiewicz, Politics and religion in seventeenth century France. A study of political ideas from the Monarchomachs to Bayle, as reflected in the toleration controversy, Berkeley 1960, s. 11; H. Höpfl, The Christian polity of John Calvin, Cambridge 1982, s. 153-158.

${ }^{64}$ E. Wolgast, Die Religionsfrage als Problem des Widerstandsrecht im 16. Jahrhundert, Heidelberg 1980; W. Schultze, Estates and the problem of resistance in theory and practice in the sixteenth and seventeenth centuries, w: Crown, church and estates, s. 158-175.

${ }^{65}$ W. Kriegseisen, op. cit., s. 190-196; R. M. Kingdon, Calvinism and resistance theory 1550-1580, w: The Cambridge history of political thought, 1450-1700, red. J. H. Burns, Cambridge 1991, s. 193-218; por. Q. Skinner, The foundations of modern political thought, cz. 2: The age of Reformation, Cambridge 2005, s. 302-348. 
wą na Węgrzech i w Czechach wskazuje nie tylko na recepcję, ale także na praktyczne wykorzystywanie tej doktryny prawa oporu w walce politycznej u schyłku XVI i w pierwszych dziesięcioleciach XVII w. ${ }^{66}$

Nieco inaczej rzecz wygląda w przypadku Rzeczypospolitej szlacheckiej, gdzie w tym okresie także wystąpiły napięcia w stosunkach pomiędzy władzą królewską a znaczną częścią społeczeństwa szlacheckiego. W ostatnim dziesięcioleciu XVI w. coraz wyraźniej zmierzająca ku centralizacji i ograniczeniu wyznaniowego równouprawnienia polityka Zygmunta III wywołała kryzys polityczny, który kulminował w latach 1606-1608 jako tzw. rokosz Zebrzydowskiego (sandomierski) ${ }^{67}$. Jednak funkcjonowanie w kulturze politycznej Rzeczypospolitej nowożytnej doktryny prawa oporu nie jest oczywiste, mimo że potwierdzono wpływ kalwinizmu na jej kształtowanie się w drugiej połowie XVI w. ${ }^{68}$ Trady- $^{-}$ cyjnie, polskie badania koncentrowały się raczej na średniowiecznej genezie prawa do oporu w związku z kształtowaniem się ustroju stanowego $^{69}$. Z kolei historycy zajmujący się epoką nowożytną skupiali się raczej

${ }^{66}$ W. Kriegseisen, op. cit., s. 198-201, 329-331; J. Pánek, The religious question and the political system of Bohemia before and after the battle of the White Mountain, w: Crown, church and estates, s. 129-148; J. Bahlcke, Calvinism and estate liberation movement in Bohemia and Hungary (1570-1620), w: The Reformation in Eastern and Central Europe, red. K. Maag, Aldershot 1997, s. 72-91; idem, Konföderation und Widerstand. Die politische Beziehungen der böhmischen Ständegemeinde, „Folia Historica Bohemica” 13, 1990, s. 235-288; K. Benda, Absolutismus und ständischer Widerstand in Ungarn am Anfang des 17. Jahrhunderts, ,Südostforschung” 33, 1974, s. 85-124; idem, Die Auswirkung der Lehren Calvins auf die Ideologie des ständischen Widerstandes in Ungarn, ,Jahrbuch der Gesellschaft für die Geschichte des Protestantismus in Österreich"110/111, 1994/1995, s. 75-85.

${ }^{67}$ K. Lepszy, Rzeczpospolita Polska $w$ dobie sejmu inkwizycyjnego (1589-1592), Kraków 1939; U. Augustyniak, Wazowie i „królowie rodacy”. Studium władzy królewskiej w Rzeczypospolitej XVII wieku, Warszawa 1999, s. 34-37; H. Wisner, W imię praw i zwyczajów, czyli wbrew nim. Rokosz Zebrzydowskiego 1606-1607, w: Król a prawo stanów do oporu, red. M. Markiewicz, E. Opaliński, R. Skowron, Kraków 2010, s. 209-221.

${ }^{68}$ E. W. Zeeden, Calvins Einwirkung auf die Reformation in Polen-Litauen. Eine Studie über den Reformator Calvin im Spiegel seiner polnischen Korrespondenten, w: Syntagma Friburgense. Historische Studien Hermann Aubin dargebracht zum 70. Geburtstag am 23.12.1955, red. M. Hellmann, H. Thieme, W. Wiora, Lindau-Konstanz 1956, s. 329-359; W. Kriegseisen, Polski przekład XX rozdziału czwartej części księgi Institutio Christianae religionis Jana Kalwina, OiRP 50, 2007, s. 101-113; K. Daugirdas, Rezeption der Theologie Calvins im Großfürstentum Litauen und Königreich Polen, w: Calvin und Calvinismus - europäische Perspektiven, red. I. Dingel, H. J. Selderhuis, Göttingen 2011, s. 155-170.

${ }^{69} \mathrm{~J}$. Szujski, Artykuł o wypowiedzeniu posłuszeństwa. Przyczynek do dziejów konstytucji polskiej, w: idem, Dzieła, ser. 2, t. 7, Kraków 1888, s. 338-360; F. Papée, O przywileju mielnickim dla senatu z r. 1501, w: Księga pamiatkowa ku czci Oswalda Balzera, t. 2, red. W. Abraham, L. Piniński, P. Dąbkowski, Lwów 1925, s. 173-187; R. Grodecki, Do genezy artykułu „o wypowiedzeniu posłuszeństwa”, „Przegląd Współczesny” 16, 1937, 61, s. 185-205; L. Sobolewski, W. Uruszczak, Artykuły mielnickie z roku 1501, CPH 42, 1990, s. 31-61; J. Wyrozumski, Od ius resistendi do ius de non praestanda oboedientia w Polsce, w: Świat, 
nad politycznymi aspektami udziału niekatolików w rokoszu Zebrzydowskiego ${ }^{70}$.

Dopiero w ostatnich latach pojawiły się nowe badania w tym zakresie. Nieco nowego wniosła publikacja Henryka Gmiterka, a przed kilku laty ukazał się tom studiów poświęconych tej problematyce ${ }^{71}$. Być może nowe perspektywy badawcze w sprawie roli prawa do oporu w nowożytnej, polsko-litewskiej kulturze politycznej otworzą niepublikowane jeszcze studia Macieja Ptaszyńskiego ${ }^{72}$. Wydaje się więc, że wpływ poreformacyjnych doktryn politycznych i prawnych w Rzeczypospolitej oraz pozostałych krajach regionu nadal jest niewyeksploatowanym zagadnieniem badawczym. Szczególnie interesujące jest to, że w całej Europie Środkowo-Wschodniej polityczne idee kalwinizmu jawią się na przełomie XVI i XVII w. jako ideologia grup broniących ustroju stanowego przed centralizacyjnymi (a więc $\mathrm{i}-\mathrm{w}$ tradycyjnym sensie - modernizacyjnymi) zakusami władz. Jest to rzecz interesująca $\mathrm{z}$ uwagi na utrwalony w literaturze pogląd o kalwinizmie jako czynniku wzmacniającym tendencje modernizacyjne ${ }^{73}$.

Uznanie doświadczenia wielowyznaniowości i współistnienia religijnego za wspólną wartość społeczeństw regionu w „długim trwaniu” epoki nowożytnej utrudniają jednak zmiany, które w tym zakresie przyniosła kontrreformacja, szczególnie efektywna na ziemiach rządzonych przez Habsburgów, a później także w Rzeczypospolitej. Intensywne promowanie przez władców katolicyzmu aspirującego do powrotu na po-

Europa, mała ojczyzna. Studia ofiarowane profesorowi Stanisławowi Grodziskiemu w 80-lecie urodzin, wyd. M. Małecki, Bielsko-Biała 2009, s. 155-164.

${ }^{70}$ A. Strzelecki, Udział i rola różnowierstwa w rokoszu Zebrzydowskiego (1606-1607), „Reformacja w Polsce” 7/8, 1935/1936, s. 101-184; J. Maciszewski, Wojna domowa w Polsce (1606-1609). Studium z dziejów walki przeciw kontrreformacji, cz. 1: Od Stężycy do Janowca, Wrocław 1960, s. 279. Problematyką nowożytnego prawa do oporu (a i to jedynie za panowania Zygmunta Augusta) zajmował się tylko Wacław Sobieski, idem, Król czy tyran? Idee rokoszowe a różnowiercy za czasów Zygmunta Augusta, „Reformacja w Polsce” 4, 1925, s. 1-14.

${ }^{71}$ H. Gmiterek, Die Rezeption reformatorischer Ideen und religiöser Widerstandstheorien innerhalb der polnischen Eliten, w: Ständefreiheit und Staatsgestaltung in Ostmitteleuropa, s. 217-227; Król a prawo stanów do oporu.

${ }^{72}$ M. Ptaszyński, Zwischen Gemeinwohl und Staatsräson. Das Widerstandsrecht in den Ständedebatten der polnisch-litauischen Republik im 16. Jahrhundert - w druku; idem, Debatten um die Grenzen der Herrschaft. Polnische Widerstandstradition und Widerstandsrecht 1501-1609 - w druku. Bardzo dziękuję autorowi za udostępnienie obu tekstów.

${ }^{73}$ O. Hintze, Kalvinismus und Staatsräson in Brandenburg zu Beginn des 17. Jahrhunderts, „Historische Zeitschrift” 144, 1931, s. 229-286; G. Oestreich, Geist und Gestalt des frühmodernen Staates. Ausgewählte Aufsätze, Berlin 1968; P.-M. Hahn, Calvinismus und Staatsbildung. Brandenburg-Preußen im 17. Jahrhundert, w: Territorialstaat und Calvinismus, red. M. Schaub, Stuttgart 1993, s. 239-269. 
zycje wyznania panującego (państwowego) zainicjowało proces katolicyzacji elit politycznych, a na przełomie XVI i XVII w. przyczyniło się do kryzysu polsko-litewskiego państwa niewyznaniowego. Nieco później w Czechach problem wyznaniowy był jedną z ważnych przyczyn konfliktu i upadku władzy stanów w 1620 r. Z kolei na Węgrzech w drugiej połowie XVII w. obserwujemy przyspieszenie katolickiej reorientacji magnackich elit i odbudowę znaczenia katolicyzmu ${ }^{74}$. Jednak procesy katolickiej konfesjonalizacji społeczeństw czeskiego, węgierskiego i polsko-litewskiego w XVII w. mają już zgoła odmienne polityczne uwarunkowania na każdym z tych terytoriów, a w związku z tym zachodzą w różnym tempie i przynoszą odmienne efekty.

Mimo to, w świetle scharakteryzowanych wyżej propozycji Müllera, problem owych rozbieżności wydaje się mieć mniejsze znaczenie - chronologiczna nieciągłość i niesymetryczność zjawiska nie musi być uznana za powód wykluczający możliwość badania go w skali regionu historycznego czy też ad hoc skonstruowanej kontrreformacyjnej „przestrzeni historycznej". Badanie wpływu kontrreformacji na stosunki wyznaniowe i polityczne w tym regionie wydaje się szczególnie potrzebne także i dlatego, że w drugiej połowie XX w. opresja ideologiczna, szczególnie silna w Czechach, krępowała swobodną refleksję w tym zakresie. Dopiero w latach dziewięćdziesiątych minionego wieku zaczęły się pojawiać interesujące prace historyków czeskich poświęcone nie tylko problematyce rekatolicyzacji $^{75}$, ale także nieomal zupełnie dotąd zapoznanej sprawie przystosowywania się elit do sytuacji politycznej po $1620 \mathrm{r}^{76}$

Warto też pamiętać, iż akcja kontrreformacyjna i wysiłki na rzecz inicjowania procesów katolickiej konfesjonalizacji w Europie Środkowo-Wschodniej do pewnego stopnia koordynowane były do przez centralne władze Kościoła rzymskokatolickiego, a „w terenie” odpowiedzialni byli za to nuncjusze papiescy. Można bronić tezy, że na przełomie XVI i XVII w. był to dla Rzymu problem zasadniczej wagi, i to nie tylko ze względu na

${ }^{74}$ G. Schramm, Wokół pojęcia, s. 16-17.

${ }^{75}$ Np. P. Balcárek, Kardinál František z Ditrichštejna (1570-1636), Kroměříž 1990; J. Honzal, Rekatolizace v Čechách. Její historický smysl a význam, „Sborník historický” 37, 1990, s. 37-91; J. Mikulec, Pobělohorská rekatolizace v českých zemích, Praha 1992; Rekatolizace v českých zemích. Sborník příspěvků z konference v Jičíně konané 10. září 1993, red. J. Francek, Pardubice 1995.

${ }^{76}$ A. M. Drabek, Die politische Haltung der böhmischen und mährischen Stände zum Herrscherabsolutismus des 17. und 18. Jahrhunderts. Von der traditionellen ständischen Rechtspositionen zu frühkonstitutionellen Forderungen, w: Ständefreiheit und Staatsgestaltung in Ostmitteleuropa, s. 265-282; J. Válka, Die „Politiques”. Konfessionelle Orientierung und politische Landesinteressen in Böhmen und Mähren (bis 1630), w: Ständefreiheit und Staatsgestaltung in Ostmitteleuropa, s. 243-241. 
politykę wobec Turcji. Świadczy o tym choćby sondażowa analiza instrukcji przygotowywanych dla nuncjuszy papieskich za episkopatu Klemensa VIII (1592-1605). Na 99 tego rodzaju dokumentów aż 25 przygotowano dla papieskich przedstawicieli zabiegających o wpływ na politykę wyznaniową władz krajów Europy Środkowo-Wschodniej ${ }^{77}$. Poza wydanymi drukiem źródłami zachowała się także wielka liczba (wydanych i niewydanych) relacji nuncjuszy i dyplomatów papieskich z krajów regionu, co pozwalałoby porównawczo analizować stan procesów kontrreformacyjnych i konfesjonalizacyjnych w Czechach, na Węgrzech i w Rzeczypospolitej $^{78}$.

Badania nad konsekwencjami akcji kontrreformacyjnej oraz procesów katolickiej konfesjonalizacji nie muszą się ograniczać do terenu Rzeczypospolitej, Korony św. Wacława oraz Korony św. Stefana. Jest to typ studiów, którym bardzo dobrze odpowiada referowany wyżej postulat M.G. Müllera konstruowania indywidualnych „przestrzeni badawczych” dla porównywania zjawisk na różnych, niekiedy odległych od siebie w przestrzeni geograficznej terytoriach. By nie być gołosłownym, odwołamy się do przykładu projektu badawczego realizowanego przez Damiena Tricoire'a, zakończonego wydaną ostatnio drukiem, interesującą monografią prezentującą okoliczności, przebieg oraz polityczne skutki rekatolizacyjnej polityki wyznaniowej w nowożytnej Francji, Bawarii i Rzeczypospolitej ${ }^{79}$.

Autor zajął się tu porównawczą analizą relacji pomiędzy religią a polityką w wybranej przez siebie europejskiej przestrzeni. W tym celu badał przejawy rekatolicyzacji w duchu reformy potrydenckiej, a przede wszystkim rosnące znaczenie kultu maryjnego, który - zgodnie z konfesjonalizacyjnym paradygmatem - był przez katolickie monarchie instrumentalizowany dla wzmocnienia ich władzy. Autor postawił jednak pytanie, czy zawsze oznaczać to musiało wzmocnienie państwa. D. Tricoire'a interesowały więc nie tylko rozwijające się w różnym tempie procesy katolickiej konfesjonalizacji w społeczeństwach bawarskim, francuskim i polsko-litewsko-ruskim, ale przede wszystkim ich polityczne konsekwencje w połowie XVII w. Jest rzeczą oczywistą, że te same środki i działania w różnych sytuacjach owocują różnymi efektami.Jednak rozważanie przyczyn, dla których forsowa-

${ }^{77}$ Die Hauptinstruktionen Clemens' VIII. für die Nuntien und Legaten an den europäischen Fürstenhöfen 1592-1605, t. 1-2, oprac. K. Jaitner, Tübingen 1984.

${ }^{78}$ Literatura związana $\mathrm{z}$ badaniami nad tzw. relacjami nuncjuszów jest obszerna, exempli gratia wskazujemy: W. Tygielski, Opinie nuncjuszy apostolskich na temat Polski XVI-XVII w., PH 84, 1994, 4, s. 351-362, idem, Z Rzymu do Rzeczypospolitej. Studia z dziejów nuncjatury apostolskiej w Polsce XVI-XVII w., Warszawa 1992.

${ }^{79}$ D. Tricoire, Mit Gott rechnen. Katholische Reform und politisches Kalkül in Frankreich, Bayern und Polen-Litauen, Göttingen 2013. 
nie reformy katolickiej we Francji i Bawarii „mimo wszystkich przeszkód i strat" ostatecznie wzmocniło te kraje, a w Rzeczypospolitej doszło do dalszego osłabienia państwa „jako pośredniej i niepożądanej, długoterminowej konsekwencji reformy katolickiej", okazało się na tyle interesujące, że można te badania prowadzone przecież w dość arbitralnie skonstruowanej „przestrzeni historycznej” uznać za udane ${ }^{80}$.

Zakończony sukcesem poznawczym wybór pola badawczego dokonany przez autora przywołanej wyżej książki potwierdza nasze przekonanie, iż niekiedy specyfika regionów historycznych rozumianych tradycyjnie jako przestrzenie geograficzne utrudnia, a nawet uniemożliwia stosowanie niektórych paradygmatów badawczych. W zakresie problemów ustrojowych i wyznaniowych takim w praktyce nieefektywnym podejściem jest w naszym przekonaniu badanie modernizacji przez konfesjonalizację ${ }^{81}$. Rozumiemy ją jako proces, w którym bliska współpraca pomiędzy oficjalnym na danym terytorium kościołem a strukturami władzy owocuje najpierw wyznaniową homogenizacją społeczeństwa i wydatnym wzmocnieniem państwa, a następnie przyspieszeniem procesu jego modernizacji ${ }^{82}$. Otóż tak rozumiane procesy w Europie Środkowo-Wschodniej, mimo że inicjowane, nie rozwinęły się, a więc i nie przyniosły modernizacyjnych skutków.

Rozpoczęte w Rzeczypospolitej na przełomie XVI i XVII w. wysiłki na rzecz katolickiej konfesjonalizacji polsko-litewsko-ruskiego społeczeństwa wobec mocnego społecznego oporu nie tylko nie wzmocniły monarchii, ale nie przyniosły nawet ujednolicenia wyznaniowego ani tym bardziej

${ }^{80}$ Ibidem, s. 389: „,trotz aller Wirren und Verwüstungen”; ,als eine indirekte und ungewollte langfristige Konsequenz der Katholischen Reform".

${ }^{81}$ Ukazały się co najmniej dwa zbiory studiów, których autorzy, kompetentnie odwołując się do paradygmatu konfesjonalizacyjnego, badali region Europy Środkowo-Wschodniej, jednak osiągnięte efekty szczegółowe nie zaowocowały przekonującymi uogólnieniami: Konfessionalisierung in Ostmitteleuropa. Wirkungen des religiösen Wandels im 16. und 17. Jahrhundert in Staat, Gesellschaft und Kultur, red.J. Bahlcke, A. Strohmeyer, Stuttgart 1999, Forschungen zur Geschichte und Kultur des östlichen Mitteleuropa, 7 - w szczególności studium W. Eberharda w tymże tomie, Voraussetzungen und strukturellen Grundlagen der Konfessionalisierung in Ostmitteleuropa, s. 89-103; Konfessionelle Formierungsprozesse im frühneuzeitlichen Ostmitteleuropa. Vorträge und Studien, red. J. Deventer, Leipzig 2006, Berichte und Beiträge des geisteswissenschaftliches Zentrums Geschichte und Kultur Ostmitteleuropas an der Universität Leipzig, z. 2.

${ }^{82}$ Najważniejsze teksty teoretyczne autorów teorii konfesjonalizacji wydano w następujących zbiorach: W. Reinhard, Ausgewählte Abhandlungen, Berlin 1997; H. Schilling, Ausgewählte Abhandlungen zur europäischen Reformations- und Konfessionsgeschichte, red. L. Schorn-Schütte, O. Mörke, Berlin 2002; zob. też Interkonfessionalität - Transkonfessionalität - binnenkonfesionelle Pluralität. Neue Forschungen zur Konfessionalisierungsthese, red. K. von Greyerz, M. Jakubowski-Tiessen, T. Kaufmann, H. Lehmann, Heidelberg 2003 i rec. tomu: M. Ptaszyński, KH 112, 2005, 2, s. 103-133. 
efektu modernizacyjnego ${ }^{83}$. Wprowadzony po 1620 r. na ziemiach Korony św. Wacława przymus wyznaniowy dał co prawda efekty w postaci formalnej rekatolicyzacji społeczeństwa, ale można mieć poważne wątpliwości co do jej głębokości i trwałości. Podobnie wysiłki władz na rzecz katolickiej konfesjonalizacji ziem węgierskich przejmowanych stopniowo spod tureckiej dominacji nigdy nie doprowadziły do ich wyznaniowej homogenizacji ${ }^{84}$. Wydaje się, że późniejsze procesy modernizacyjne na tych ziemiach mają zupełnie inną genezę i nie należy ich wiązać z próbami spóźnionej i częściowo tylko skutecznej katolickiej konfesjonalizacji w XVII w.

Przyczyny tego opóźnienia i nieefektywności procesów konfesjonalizacyjnych w Europie Środkowo-Wschodniej łatwo wyjaśnić. Niezbędnym warunkiem modernizacji państwa przez konfesjonalizację jest bowiem, jak to już wyżej powiedziano, współpraca administracji państwa ze strukturami władzy Kościoła panującego. Tam, gdzie - jak np. w Rzeczypospolitej szlacheckiej - państwo obywało się w praktyce bez rozbudowanych struktur administracyjnych, a Kościół katolicki długo zabiegać musiał o formalne przywrócenie mu statusu wyznania panującego, sukces katolickiej konfesjonalizacji był po prostu niemożliwy. I nie stanowiło to w nowożytnej Europie jedynego przykładu nieskuteczności procesów konfesjonalizacyjnych z przyczyny słabości państwa. Decentralizacja i słabe struktury administracyjne zadecydowały także o braku konfesjonalizacyjnego sukcesu wyznania ewangelicko-reformowanego w Zjednoczonych Prowincjach Niderlandów Północnych ${ }^{85}$. Mimo że w drugiej połowie XVII w. kalwinizm był tam nie tylko wyznaniem oficjalnie popieranym i chronionym przez władze, ale także uzyskał liczebną przewagę nad wyznawcami innych chrześcijańskich konfesji, mimo że „nadere reformatie” („dalsza reformacja” rozumiana jako wzmocnienie wyznaniowej identyfikacji oraz pogłębienie życia duchowego) przyniosła spektakularne efekty, to jednak niderlandzki Kościół Ewangelicko-Reformowany nigdy w tym okresie nie uzyskał oficjalnej pozycji wyznania państwowego, a więc Zjednoczone Prowincje Niderlandów Północnych do końca istnienia w sensie

${ }^{83}$ W. Kriegseisen, Stosunki wyznaniowe w relacjach państwo-kościót, s. 576-660.

${ }^{84}$ I. Keul, Early modern religious communities in East-Central Europe. Ethnic diversity, denominational plurality, and corporative politics in the Principality of Transylvania (15261691), Leiden 2009, s. 219-270.

85 O. Mörke, „Konfessionalisierung” als politische-soziales Strukturprinzip? Das Verhältnis von Religion und Staatsbildung in der Republik der Vereinigten Niederlande im 16. und 17. Jahrhundert, ,"Tijdschrift voor Sociale Geschiedenis” 16, 1990, 1, s. 31-60; idem, Die politische Bedeutung des Konfessionellen im Deutschen Reich und in der Republik der Vereinigten Niederlande oder: War die Konfessionalisierung ein „Fundamentalvorgang”, w: Der Absolutismus - ein Mythos?, s. 125-164. 


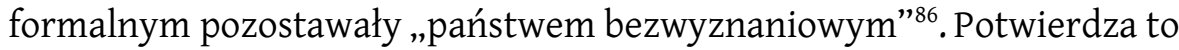
nasze przekonanie, że na europejskim tle tolerancyjna Rzeczpospolita w XVI i XVII w. nie była, przynajmniej w zakresie stosunków wyznaniowych, nieporównywalnym $z$ innymi państwami fenomenem ${ }^{87}$. Zachęca to do prowadzenia badań porównawczych nie tylko w jednoznacznie geograficznie zdefiniowanym regionie Europy Środkowo-Wschodniej, ale także do szukania poza nim pól do badań porównawczych.

\section{The Historical Region of East-Central Europe in Research into the History of Religion in the Modern Era}

Regional divisions have been examined in research focused on the history of Europe for long and not always from merely the workshop vantage point. The inclusion of a territory (tribal, state, national) into a given region possesses, as a rule, important political and ideological implications. On the other hand, pertinent scientific debates should refer to concrete problems and at times even research projects intent on seeking solutions and answers involving the application of comparative studies.

This minimal condition for studies about East-Central Europe was introduced as early as 1950 by Oskar Halecki. The functionality of the regional division of Europe proposed by Halecki was confirmed for East-Central Europe predominantly thanks to studies on the economy, assorted political-systemic questions and the specific political culture of the region. Recently, this assumption was confirmed, while modifying the idea launched by Halecki, by the research proposals formulated by Michael G. Müller, a German historian specialising in the history of East Europe.

The process of distinguishing the region of East-Central Europe proves also useful in studies on the history of religion from the sixteenth to the eighteenth century since alongside the manorial-corvée economy and the estate system featuring the predominance of the gentry, it was precisely the extremely high level of religious and creed variety that was one of the most characteristic and permanent features of modern societies in East-Central Europe: the Polish-Lithuanian Commonwealth of the gentry, the lands of the Crown of St. Wenceslas, and the lands of the Crown of St. Stephen.

Translated by Aleksandra Rodzińska-Chojnowska

${ }^{86}$ W. Kriegseisen, Stosunki wyznaniowe w relacjach państwo-kościót, s. 359-408.

${ }^{87}$ A. Manikowski, Czy siedemnastowieczna Rzeczpospolita była anomalia wśród innych państw europejskich?, OiRP 37, 1993, s. 79-87; W. Tygielski, Rzeczpospolita szlachecka: paradoks historii czy europejska norma?, w: Tematy polsko-białoruskie. Historia. Literatura. Edukacja, red. R. Traba, Olsztyn 2003, s. 40-53. 